\title{
Preparation of low-fat paneer using Glucono delta-lactone as an acidulant
}

\author{
Mamata Chaudhary, Suneeta Pinto, CN Dharaiya and Preeti Paul
}

Received: 17 September 2020 / Accepted: 04 December 2020 / Published online: 28 February 2021

(C) Indian Dairy Association (India) 2021

\begin{abstract}
The study was aimed to develop a process to manufacture low-fat paneer using glucono delta-lactone as an acidulant. Carboxymethyl cellulose was used as a fat replacer. Low-fat paneer was prepared from $1.0 \%$ fat mixed milk (Cow:Buffalo::55:45). Optimization of the manufacturing parameters was carried out by using Response Surface Methodology with central composite rotatable design using three independent variables viz. coagulation temperature, level of carboxymethyl cellulose and strength of glucono delta-lactone solution. The suggested solution from RSM analysis for low-fat paneer was coagulation temperature: $80^{\circ} \mathrm{C}$, level of carboxymethyl cellulose: $600 \mathrm{mg} / \mathrm{kg}$ milk and strength of glucono delta-lactone solution: $2 \%$. The developed product had $64.10 \pm 0.82 \%$ moisture, $6.53 \pm 0.16 \%$ fat and $18.21 \pm 1.01 \%$ FDM. The product had $27 \%$ higher protein and about 4 times less fat as compared to regular paneer. Results of the study revealed that an acceptable quality low-fat paneer can be manufactured by incorporating hydrocolloid and glucono delta-lactone.
\end{abstract}

Keywords: Carboxymethyl cellulose, Glucono delta-lactone, Low-fat paneer, Response surface methodology

Dairy Technology Department, SMC College of Dairy Science, Anand Agricultural University, Anand, India

CN Dharaiya $(\square)$

Dairy Technology Department, SMC College of Dairy Science, Anand Agricultural University, Anand, India

E-mail ID: chetandharaiya@gmail.com

Mobile No.: +91 7573013697

\section{Introduction}

Paneer is a heat and acid coagulated traditional Indian dairy product. In India, paneer production has been largely confined to the small unorganized sectors. Paneer is a soft cheese like product which is rich in fat and protein. The average fat content of paneer varies between 23 to $26 \%$ while protein content varies between 17 to $21 \%$. Scientific evidence links high-fat diets with increased risk of obesity, atherosclerosis, high blood pressure and tissue injury (Madadlou et al. 2005). This has necessitated a higher demand for low-fat foods. Low-fat products are formulated or designed so as to meet the dietary needs of obese people, people at risk of cardiovascular disease, diabetics and people on diets for weight management (Sandrou and Arvanitoyannis 2003). The high cost of paneer is mainly attributed to its high fat content $(23-26 \%)$ due to which many low and middle class income people refrain from consuming it and cannot afford to include it in their regular diet.

The role of fat in the development of acceptable flavour, body and texture as well as appearance of paneer is unquestionable. A reduction in fat content of paneer results in lower acceptability. Usually, low-fat cheese varieties are usually characterized by rubbery texture, flat flavour, poor meltability and undesirable dull colour lacking glossiness compared to their full fat counterparts (Mistry 2001). In literature, it has been reported that fat reduction in dairy products can be achieved by replacing fat with starches, polysaccharides, gums or fibres from cereal, vegetables and fruits (Tufeanu and Tia 2016). Murtaza et al. (2017) prepared low-fat cheddar cheese from $2.0 \%$ fat buffalo milk by adding xanthan gum and guar gums at different rates varying from 0.15 to $0.45 \%$. They reported that guar gum can effectively be used @ $0.45 \%$ to produce a low-fat Cheddar cheese with functional, textural and sensory characteristics which were comparable to full fat cheese.

Glucono- $\delta$-lactone (GDL), an acidulant, is a non-agricultural additive which can be produced in a non-synthetic way. GDL hydrolyses in water to form gluconic acid. The rate of acid formation is affected by temperature, concentration and the $\mathrm{pH}$ of the solution. It has low acid release at room temperature, but the rate of conversion to gluconic acid increases as the temperature increases (Fetahagić et al. 2002). It has been reported 
to be one of the best acids to reduce $\mathrm{pH}$ without adversely affecting the acidic flavour profile of food products (Lucey and Kelly, 1994). It is commonly used for manufacture of silken soft tofu (Guo and Ono 2005). Shin et al. (2014) developed a low-fat tofu using GDL as acidulant. They reported that the physicochemical and sensory properties were comparable to fullfat tofu.

It was hypothesized that use of hydrocolloids in combination with GDL would help in improving the body and texture characteristics of low -fat paneer. Hence a low-fat paneer was prepared using GDL as an acidulant in combination with hydrocolloids.

\section{Materials and Methods}

Whole milk (6.1\% fat $/ 9.1 \%$ MSNF), standardized milk ( $4.5 \%$ fat/ $8.5 \% \mathrm{MSNF})$ and skim milk ( $0.2 \%$ fat $/ 9.1 \% \mathrm{MSNF})$ were collected from Vidya Dairy, Anand. Carboxymethyl cellulose (CMC) (Lobachemicals private Ltd., Mumbai) and Glucono delta-lactone (GDL) (Roquette India Pvt. Ltd., Mumbai) were used as a hydrocolloid and an acidulant respectively in low-fat paneer (LFP). Citric acid (Loba-chemicals private Ltd., Mumbai) used as coagulant for manufacture of control sample of paneer.

\section{Preparation of paneer}

Low-fat paneer was prepared using different levels of CMC, coagulation temperatures and strengths of GDL solution as suggested by Response Surface Methodology (RSM) to choose the best combination to get the most acceptable LFP. The selected range on the basis of preliminary trials were: 75 to $85^{\circ} \mathrm{C}$ for coagulation temperature (A), 600 to $900 \mathrm{mg} / \mathrm{kg}$ of milk for level of CMC (B) and 2.0 to $4.0 \%$ strength of GDL solutions (C). At temperatures lower than $75^{\circ} \mathrm{C}$ and lower strength of GDL solutions the curd was too soft to handle and at temperatures higher than $85^{\circ} \mathrm{C}$ and higher than $4 \%$ strength of GDL the paneer lacked the desired firmness and became too hard. Higher levels of CMC i.e. higher than $900 \mathrm{mg} / \mathrm{kg}$ affected the body and texture of paneer adversely and it became too sticky. The solutions were optimized by adopting a three factor Central Composite Rotatable Design (CCRD) consisting of total 20 experiments Table 1.

Milk (standardized to $1.0 \%$ fat) was heated to $40-45^{\circ} \mathrm{C}$ and $\mathrm{CMC}$ (level mentioned in Table 1) was added in the form of a paste (prepared in lukewarm milk, about 100 times its weight). Milk was further heated to $90^{\circ} \mathrm{C}$ for $5 \mathrm{~min}$, cooled to the coagulation temperature (as mentioned in Table 1) and coagulated with GDL solution (strength as mentioned in Table 1), pre-heated to coagulation temperature, which was added slowly to the milk with slow stirring until a coagulum and clear whey separated out. The coagulum was allowed to settle for $5 \mathrm{~min}$ for completion of the coagulation process. Care was taken to see that the temperature of whey was above $70^{\circ} \mathrm{C}$ at the time of draining. Draining of whey was completed in $5 \mathrm{~min}$. The coagulum was transferred to a rectangular sterilized stainless steel paneer hoop lined with a clean and sterile muslin cloth. The curd was pressed for $20 \mathrm{~min}$ by applying a pressure of 2.0 to $2.5 \mathrm{~kg} / \mathrm{cm}^{2}$. Paneer blocks were removed from the hoop and immersed in pasteurized chilled water (about $4^{\circ} \mathrm{C}$ ) for 2 hours. The drained paneer blocks (200 g each) were vacuum packed in pre-sterilized laminated pouches with UV light ( $12 \mu$ polyester $+50 \mu \mathrm{LD} / \mathrm{LLDPE})$ and stored at $7 \pm 1^{\circ} \mathrm{C}$. Control sample of paneer (CP) was prepared from standardized milk ( $4.5 \%$ fat $/ 8.5 \%$ SNF milk) using the method described by Aneja et al. (2002).

\section{Physico-chemical analysis}

Moisture, fat, protein and ash content as well as titratable acidity and $\mathrm{pH}$ of paneer samples were determined as per the procedure described by FSSAI (2015) .

\section{Textural analysis}

Two-bite compression testing of paneer samples was done with Lloyd Instrument, Hampshire, UK (Model No. 01/2962) using 5 $\mathrm{KN}$ load-cells which moved at a speed of $20 \mathrm{~mm} / \mathrm{min}$. All the textural measurements were conducted in a room maintained at $23 \pm 1{ }^{\circ} \mathrm{C}$ temperature and $65 \pm 1 \% \mathrm{RH}$. The paneer samples were taken for texture measurement after tempering the same at $20 \pm 1^{\circ} \mathrm{C}$. Cubic samples of the experimental paneer, with edges of $2.00 \pm 0.06$ $\mathrm{cm}$, were placed in such a manner that fibers were oriented perpendicular to the cylindrical compression anvil. The cubic samples were compressed up to $70 \%$ of their initial size. Average of five cubic samples was reported.

\section{Sensory evaluation}

Each block of paneer was cut into approximately $25 \mathrm{~g}$ rectangular pieces and tempered to $20 \pm 2^{\circ} \mathrm{C}$ before judging. The sensory panel $(n=9)$ was composed of faculty members of the institute. The products were evaluated using 100-point scale as described in IS: 15346 (2003) in a well-ventilated sensory evaluation laboratory. Lukewarm water was uses for rinsing mouth.

\section{Statistical analysis}

The data was analysed using Response Surface Methodology (RSM) Design Expert (Version 8.0.3) which was employed to carry out optimization of selected parameters in the final product formulation. Comparison of LFP with CP was analysed using Completely Randomized Design (CRD).

\section{Results and Discussion}

All the 20 batches of LFP were evaluated for their sensory and textural attributes as well as selected compositional parameters. The results of the study obtained for sensory scores, textural properties and selected compositional attributes of LFP are presented in Table 1. The regression analysis of suggested models 
for sensory scores, textural properties and FDM (fat on dry matter basis) of low -fat paneer is presented in Table 2.

\section{Effect of coagulation temperature, level of CMC and strength of GDL solution on sensory characteristics of low -fat paneer}

As seen in Table 2 that the calculated F-values are more than the Table F-values at 5\% level of significance which indicate the significance of the model terms. It can also be seen that, the coefficient of determination $\left(\mathrm{R}^{2}\right)$ which reflects the proportion of variability in data explained or accounted by the model for flavour, body and texture, colour and appearance and total score were $0.8950,0.8507,0.8094$ and 0.8624 respectively. A larger $\mathrm{R}^{2}$ values suggest a better fit of the quadratic model. The Adequate Precision Value (APV) measure the signal to noise ratio. As seen in Table 2, the APV for sensory characteristics were greater than 4 , which support the suitability of the model to navigate the design.

\section{Flavour}

The flavour score of LFP ranged from 37.7 to 42.2 out of 50 (Table 1). A significant $(\mathrm{P}<0.01)$ reduction in flavour score was observed with increase in strength of GDL solution (C). The interaction of coagulation temperature and level of $\mathrm{CMC}(\mathrm{AB})$ in milk showed significant $(\mathrm{P}<0.05)$ negative effect. At quadratic level, coagulation temperature and strength of GDL solution reduced flavour score significantly at $5 \%$ and $1 \%$ level respectively while level of CMC significantly $(\mathrm{P}<0.05)$ improved flavour score.

The results obtained in this study are in contrast to those reported by Ghosh et al. (2019), who observed reduction in the flavour score of LFP, prepared from $0.5 \%$ fat cow milk using $1 \%$ solution of citric acid as a coagulant, with increase in coagulation temperature from 65 to $80^{\circ} \mathrm{C}$. Whereas, in present study, the highest flavour score was obtained at $80^{\circ} \mathrm{C}$ coagulation temperature. The difference observed could be due to the differences in type and level of coagulants used and type of milk used. Similar results were observed by Murtaza et al. (2017) who reported that with increase in level of guar gum (from 0.15 to $0.45 \%$ ), an increase in flavour score of low-fat Cheddar cheese prepared from buffalo milk (2.0\% fat) was observed. Salari et al. (2017) prepared cream cheese by addition of hydrocolloids such as xanthan gum and $\mathrm{CMC}$ and reported an improvement in taste of the product. The reduction in the flavour score could be

Table 1 Experimental design matrix and sensory characteristics, textural properties and FDM of low -fat paneer

\begin{tabular}{|c|c|c|c|c|c|c|c|c|c|c|c|}
\hline $\begin{array}{l}\text { Run } \\
\text { Order }\end{array}$ & $\begin{array}{c}\text { Coagu } \\
\text { lation } \\
\text { Tempe } \\
\text { rature } \\
\left({ }^{\circ} \mathrm{C}\right) \\
\text { (A) }\end{array}$ & $\begin{array}{c}\text { Level } \\
\text { of } \\
\text { CMC } \\
\text { (mg/k } \\
\text { g } \\
\text { milk) } \\
\text { (B) }\end{array}$ & $\begin{array}{c}\text { Streng } \\
\text { th of } \\
\text { GDL } \\
\text { solutio } \\
\text { n }(\%) \\
\text { (C) }\end{array}$ & $\begin{array}{c}\text { Flavou } \\
\text { r } \\
\text { Score } \\
\text { (Out } \\
\text { of 50) }\end{array}$ & $\begin{array}{c}\text { B \& T } \\
\text { Score* } \\
\text { (Out } \\
\text { of 35) }\end{array}$ & $\begin{array}{c}\text { C \& A } \\
\text { Score } \\
@ \\
\text { (Out } \\
\text { of } 10)\end{array}$ & $\begin{array}{c}\text { Total } \\
\text { Score* } \\
* \\
\text { (Out } \\
\text { of } \\
100)\end{array}$ & $\begin{array}{c}\text { Hardn } \\
\text { ess } \\
(\mathrm{N})\end{array}$ & $\begin{array}{c}\text { Chewi } \\
\text { ness } \\
(\mathrm{Nmm} \\
\text { ) }\end{array}$ & $\begin{array}{l}\text { Cohesi } \\
\text { veness }\end{array}$ & $\begin{array}{c}\mathrm{FDM}^{\#} \\
(\%)\end{array}$ \\
\hline 3 & 85.00 & 900.00 & 4.00 & 39.00 & 30.25 & 8.50 & 82.75 & 25.14 & 83.11 & 0.513 & 17.32 \\
\hline 4 & 88.41 & 750.00 & 3.00 & 39.20 & 29.00 & 8.35 & 81.55 & 23.34 & 75.67 & 0.500 & 17.49 \\
\hline 5 & 80.00 & 497.73 & 3.00 & 41.00 & 31.25 & 8.25 & 85.50 & 23.77 & 74.40 & 0.501 & 21.23 \\
\hline 6 & 80.00 & 750.00 & 3.00 & 40.45 & 28.89 & 8.37 & 82.72 & 19.54 & 60.91 & 0.500 & 17.74 \\
\hline 11 & 75.00 & 900.00 & 2.00 & 39.40 & 31.00 & 8.00 & 83.40 & 15.35 & 43.77 & 0.462 & 21.26 \\
\hline 12 & 71.59 & 750.00 & 3.00 & 39.20 & 31.20 & 8.20 & 83.60 & 17.16 & 48.34 & 0.505 & 17.29 \\
\hline 13 & 80.00 & 750.00 & 3.00 & 40.60 & 28.90 & 8.25 & 82.75 & 19.45 & 60.50 & 0.492 & 18.29 \\
\hline 14 & 80.00 & $\begin{array}{c}1002.2 \\
7\end{array}$ & 3.00 & 42.20 & 31.80 & 8.20 & 87.20 & 14.59 & 44.29 & 0.478 & 22.15 \\
\hline 15 & 75.00 & 900.00 & 4.00 & 41.40 & 31.20 & 8.12 & 85.72 & 13.85 & 39.37 & 0.478 & 22.06 \\
\hline 16 & 80.00 & 750.00 & 1.32 & 39.60 & 28.90 & 8.20 & 81.70 & 14.08 & 42.97 & 0.499 & 18.07 \\
\hline 17 & 85.00 & 600.00 & 2.00 & 42.00 & 30.20 & 8.20 & 85.40 & 20.28 & 62.61 & 0.515 & 19.20 \\
\hline 18 & 80.00 & 750.00 & 3.00 & 40.20 & 29.20 & 8.30 & 82.70 & 17.53 & 60.50 & 0.506 & 18.29 \\
\hline 19 & 80.00 & 750.00 & 3.00 & 40.80 & 28.00 & 8.20 & 82.00 & 19.54 & 60.32 & 0.513 & 17.96 \\
\hline
\end{tabular}




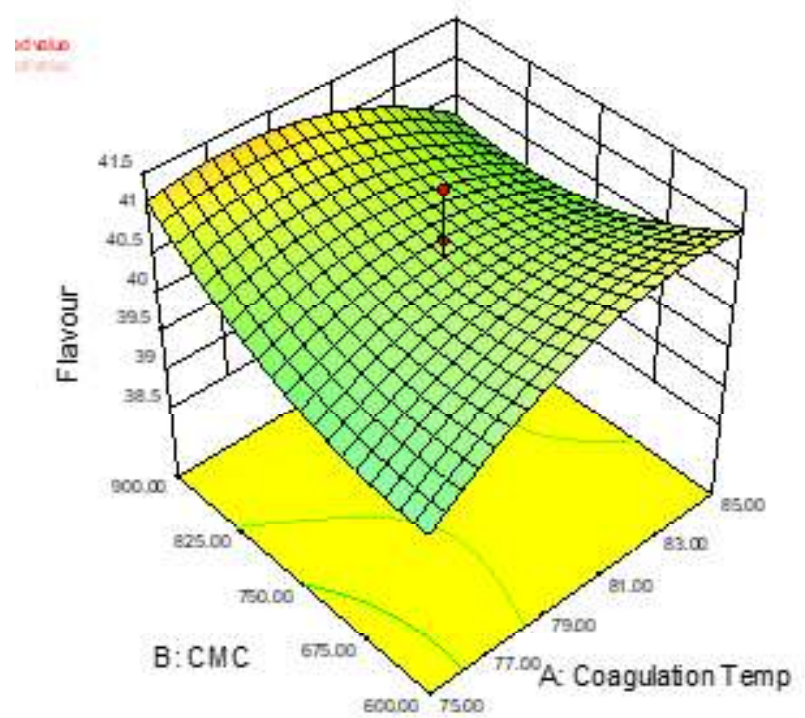

(a) Response surface of flavour as influenced by coagulation temperature $\left({ }^{\circ} \mathrm{C}\right)$ and level of $\mathrm{CMC}(\mathrm{mg} / \mathrm{kg}$ milk)

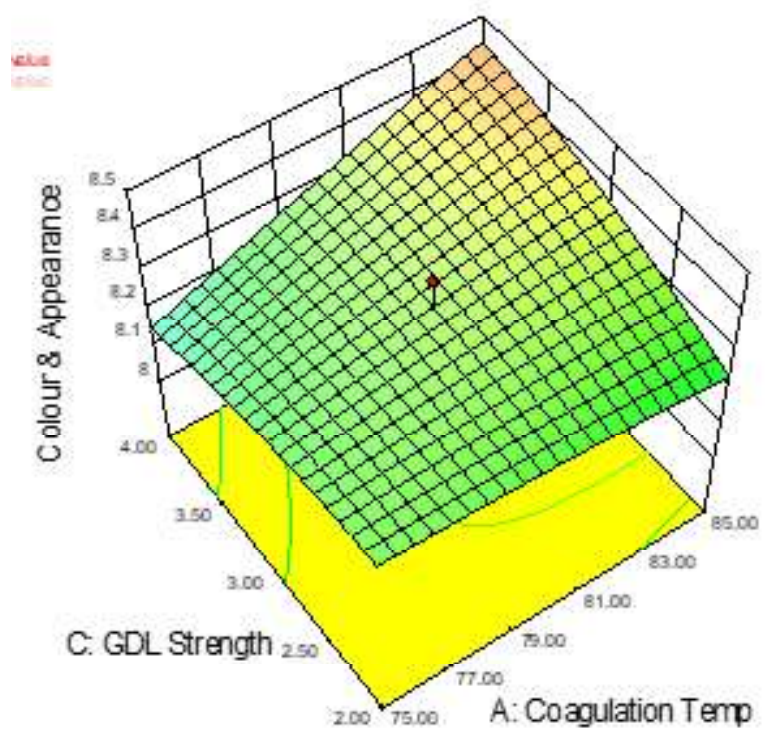

(c) Response surface of colour and appearance as influenced by coagulation temperature $\left({ }^{\circ} \mathrm{C}\right)$ and strength of GDL solution $(\%)$

Fig. 1 Surface plot (3-D) for sensory characteristics of low -fat paneer

ascribed to lack of richness and flat flavour owing to lower fat content.

\section{Body and Texture}

The body and texture score of LFP as depicted in Table 1 varied from 27.9 to 31.8 (out of 35). The values from Table 2 suggested the coagulation temperature of milk showed significant $(\mathrm{P}<0.05)$ negative effect. At quadratic level, body and texture score

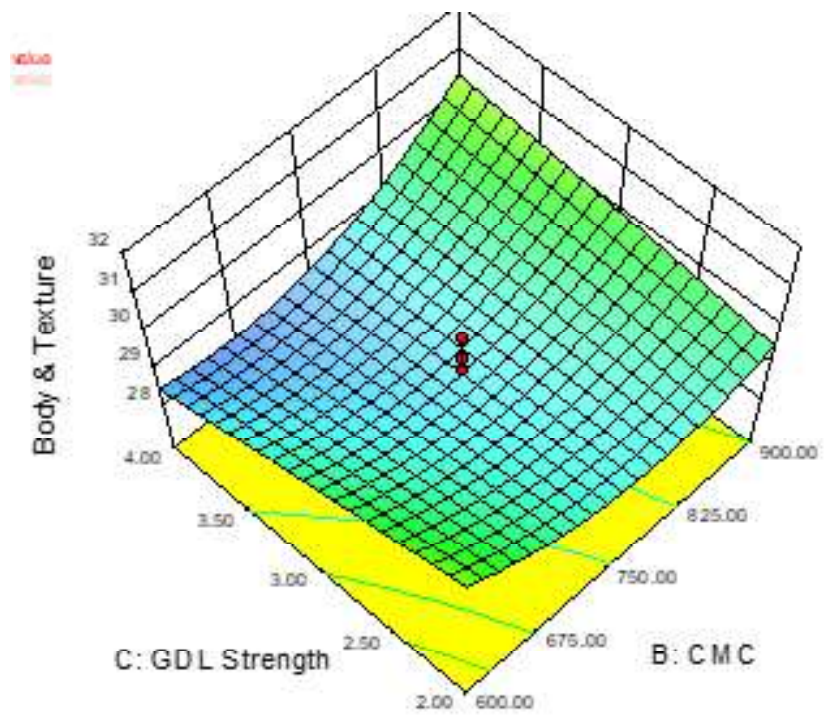

(b) Response surface of body and texture score as influenced by level of CMC ( $\mathrm{mg} / \mathrm{kg}$ milk) and Strength of GDL solution $(\%)$

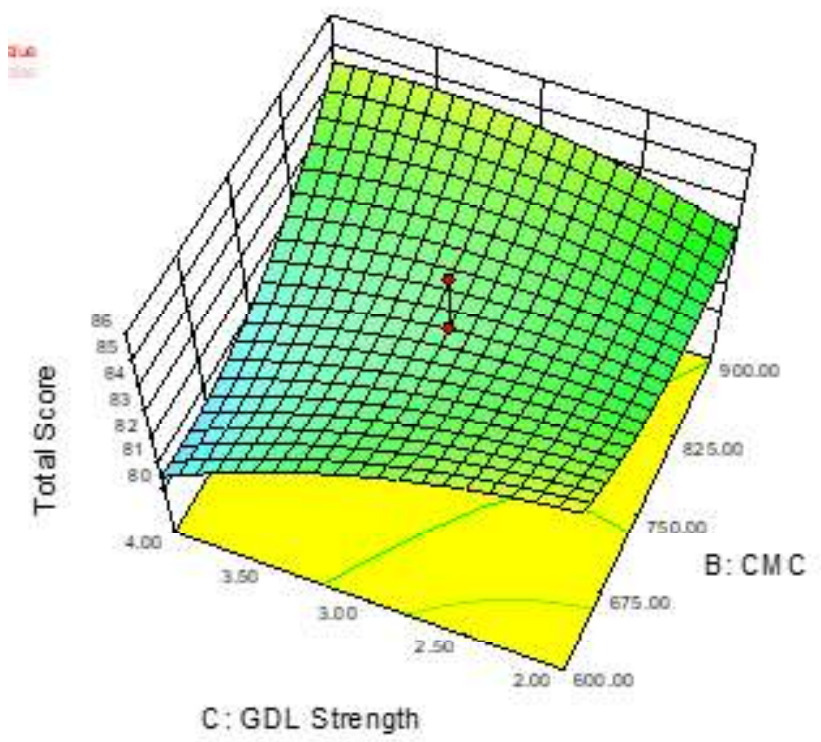

(d) Response surface of total score as influenced by level of $\mathrm{CMC}(\mathrm{mg} / \mathrm{kg}$ milk) and strength of GDL solution (\% significantly increased with increase in coagulation temperature $(\mathrm{P}<0.05)$ and level of $\mathrm{CMC}(\mathrm{P}<0.01)$. Interaction of level of $\mathrm{CMC}$ and strength of GDL solution $(\mathrm{BC})$ had significant $(\mathrm{P}<0.05)$ positive effect (Fig. 1(b)).

The results obtained in this study are in contrast to those reported by Ghosh et al. (2019) who reported that the body and texture score of low-fat paneer prepared from $0.5 \%$ fat cow milk increased when milk coagulation temperature increase from 50 to $60^{\circ} \mathrm{C}$ and 

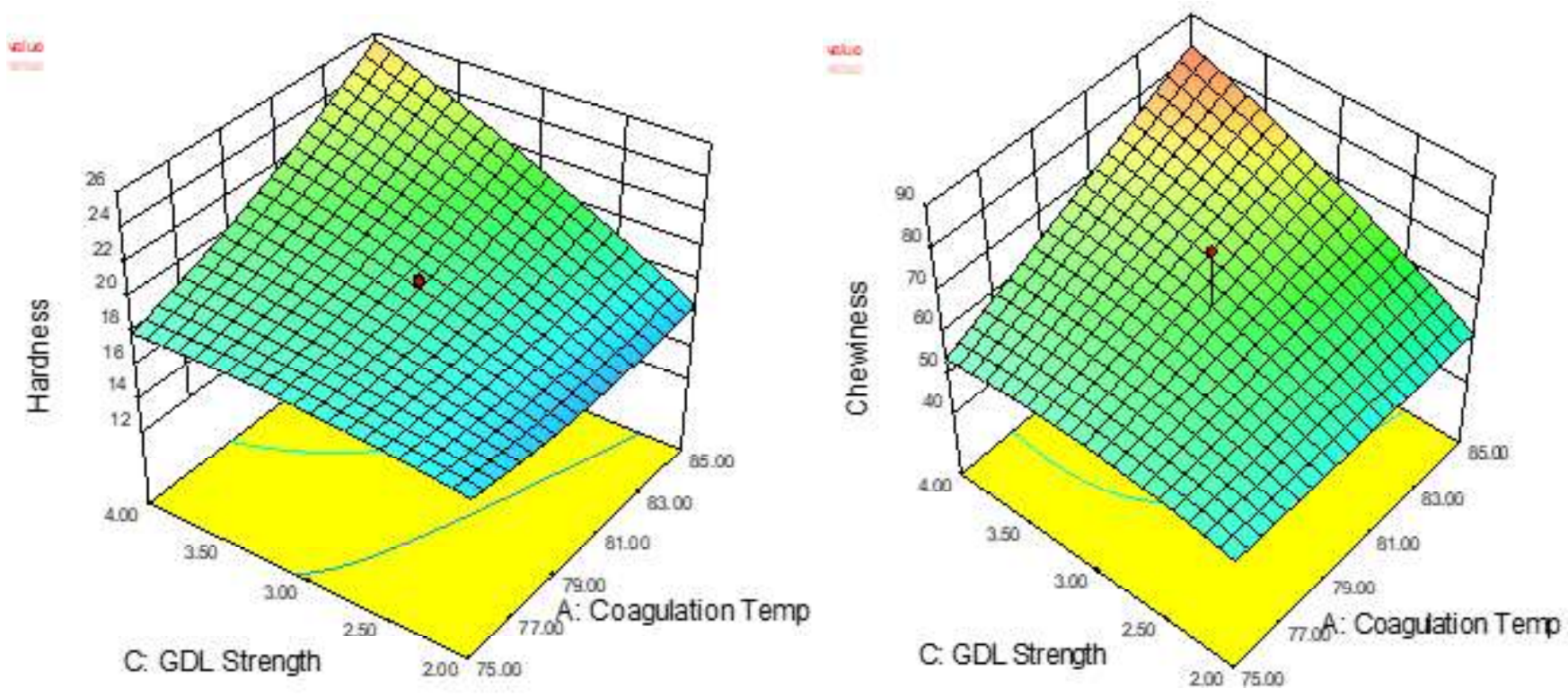

(a) Response surface of hardness as influenced by coagulation temperature $\left({ }^{\circ} \mathrm{C}\right)$ and strength of GDL solution $(\%)$

(b)

Response surface of chewiness as influenced by coagulation temperature $\left({ }^{\circ} \mathrm{C}\right)$ and strength of GDL solution $(\%)$

then decreased when coagulation temperature increase from 65 to $80^{\circ} \mathrm{C}$. Whereas, in current study, it was found that the highest body and texture scores was obtained when the coagulation temperature was $80^{\circ} \mathrm{C}$. The difference observed could be attributed to the differences in type and level of ingredients used and type of milk used. Low fat paneer is characterised by hard body, while addition of hydrocolloids like CMC helped in moisture retention by water-binding and thus increased moisture content which resulted in softer body and ultimately led to higher body and texture score.

\section{Colour and Appearance}

The colour and appearance scores of LFP depicted in Table 1 varied from 8.0 to 8.5 (out of 10). The observations from Table 2 suggested significant $(\mathrm{P}<0.05)$ increase in colour and appearance score with increase in coagulation temperature. Interaction of coagulation temperature with $\mathrm{CMC}(\mathrm{AB})$ or strength of GDL solution (AC) (Fig. 1(c)) and interaction of CMC and strength of GDL solution (BC) showed significant positive effect.

Ghosh et al. (2019) also reported that the positive correlation of milk coagulation temperature with colour and appearance of paneer of low-fat paneer prepared from $0.5 \%$ fat cow milk. Singh et al. (2015) also observed similar observation in low-fat fibre supplemented paneer ( $3.0 \%$ fat milk). Similar observations were made by Murtaza et al. (2017) who reported that with increases level of guar gum there was an increase in colour and appearance score of low-fat Cheddar cheese prepared from buffalo milk $(2.0 \%$ fat). The higher score for colour and appearance could be

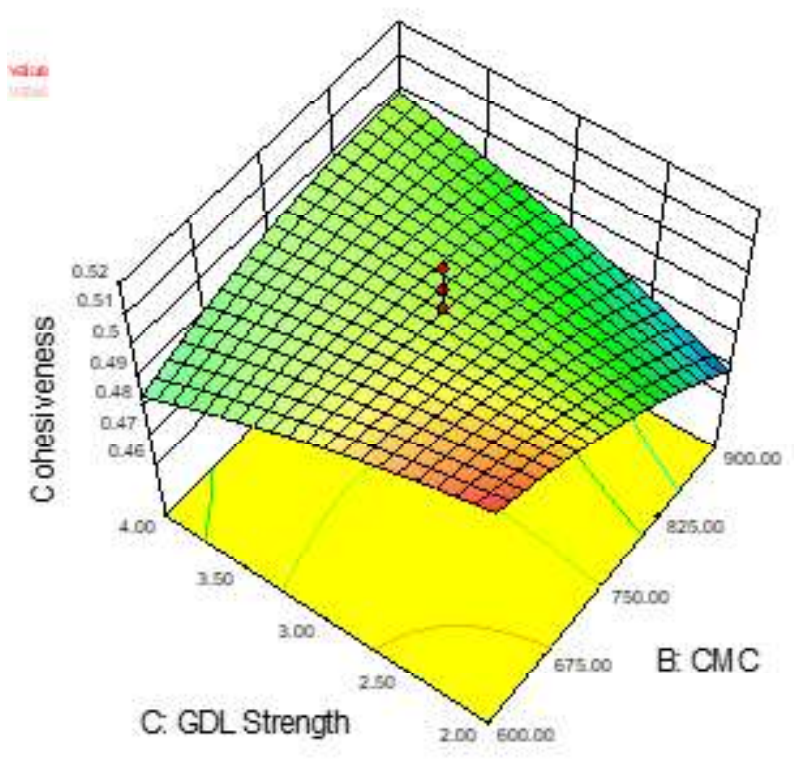

(c) Response surface of cohesiveness as influencedby level of $\mathrm{CMC}(\mathrm{mg} / \mathrm{kg}$ milk) and strength ofGDL solution (\%)

Fig. 2 Surface plot (3-D) for textural properties of low -fat paneer

attributed to higher glossiness due to higher moisture content because of addition of CMC.

\section{Total score}

The total score of LFP depicted in Table 1 ranged from 78.82 to 87.20 (out of 100). The observations from Table 2 suggested 


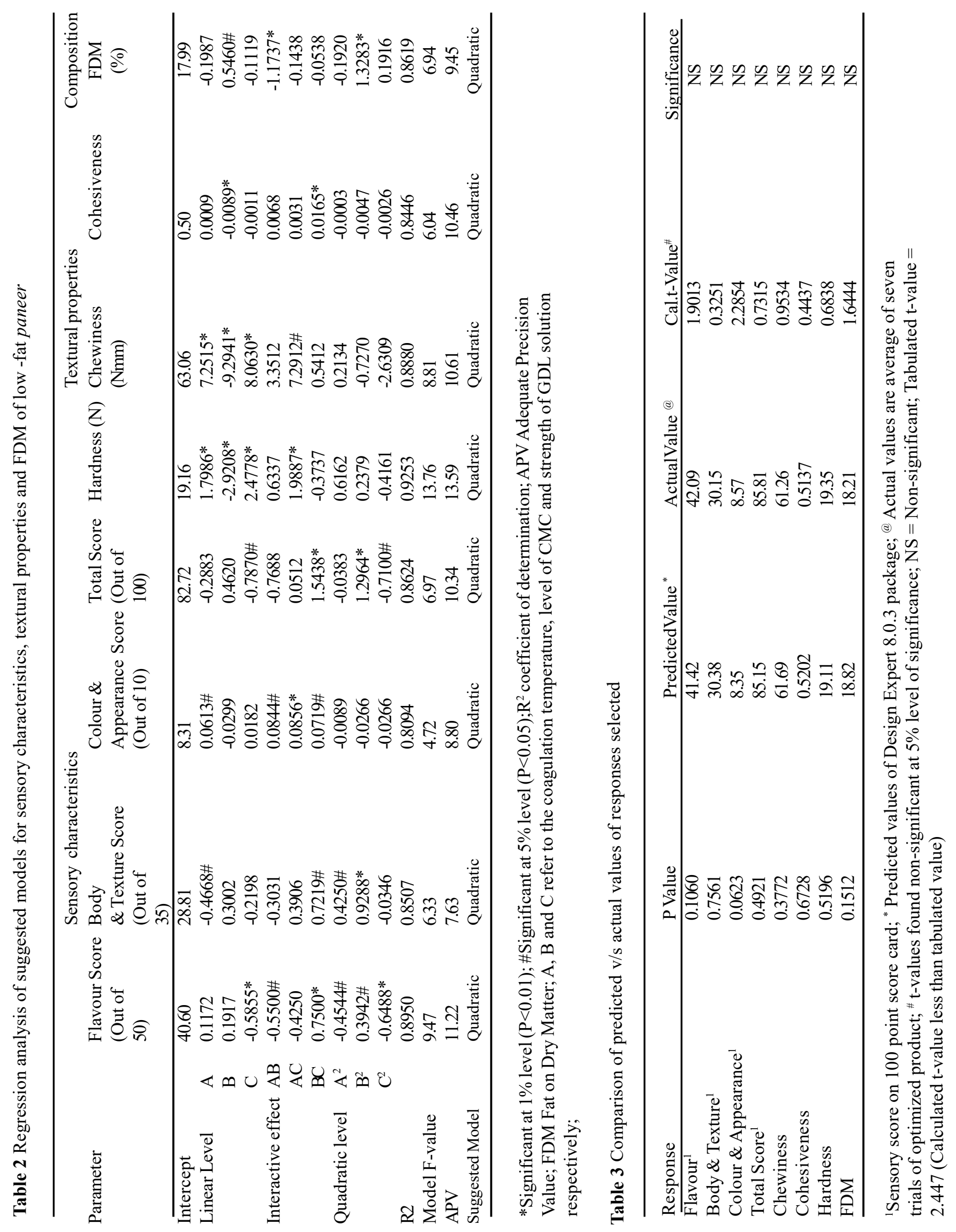


Table 4 Comparison of proximate composition, sensory and textural properties of low -fat paneer with control paneer

\begin{tabular}{lllc}
\hline Components & CP(Citric acid) & LFP(GDL+CMC) & CD $(0.05)$ \\
\hline Moisture (\%) & $61.80 \pm 0.82$ & $64.10 \pm 0.64$ & 0.89 \\
Fat (\%) & $8.92 \pm 0.48$ & $6.53 \pm 0.16$ & 0.42 \\
FDM & $18.94 \pm 1.01$ & $18.21 \pm 0.33$ & $\mathrm{NS}$ \\
Protein (\%) & $23.35 \pm 0.77$ & $22.07 \pm 0.37$ & 0.72 \\
Ash (\%) & $2.62 \pm 0.12$ & $2.45 \pm 0.15$ & $\mathrm{NS}$ \\
Carbohydrate (\%) & $3.26 \pm 0.29$ & $4.84 \pm 0.27$ & 0.34 \\
Acidity (\%LA) & $0.45 \pm 0.015$ & $0.47 \pm 0.019$ & $\mathrm{NS}$ \\
pH & $5.96 \pm 0.025$ & $5.94 \pm 0.029$ & $\mathrm{NS}$ \\
\% Fat recovery & $87.37 \pm 1.43$ & $87.87 \pm 2.38$ & $\mathrm{NS}$ \\
\% Total solids recovery & $47.67 \pm 0.96$ & $46.61 \pm 0.66$ & $\mathrm{NS}$ \\
\% Yield & $12.29 \pm 0.65$ & $13.42 \pm 0.35$ & 0.62 \\
Flavour Score (Out of 50) & $45.05 \pm 1.94$ & $42.09 \pm 2.27$ & 2.46 \\
Body \& Texture Score (Out of 35) & $31.57 \pm 1.62$ & $30.16 \pm 1.78$ & $\mathrm{NS}$ \\
Colour and Appearance Score (Out of 10) & $8.21 \pm 0.23$ & $8.57 \pm 0.31$ & 0.32 \\
Total Score (Out of 100) & $89.84 \pm 2.56$ & $85.81 \pm 3.42$ & 3.52 \\
Hardness (N) & $22.93 \pm 1.75$ & $19.34 \pm 1.22$ & 1.80 \\
Cohesiveness & $0.46 \pm 0.02$ & $0.52 \pm 0.03$ & 0.04 \\
Chewiness (Nmm) & $64.17 \pm 2.79$ & $61.26 \pm 3.29$ & $\mathrm{NS}$ \\
Springiness (mm) & $6.08 \pm 0.29$ & $6.38 \pm 0.23$ & $\mathrm{NS}$ \\
Gumminess (N) & $10.55 \pm 0.51$ & $9.17 \pm 0.49$ & 0.61 \\
\hline
\end{tabular}

strength of GDL solution had significant $(\mathrm{P}<0.05)$ negative effect on total score at linear level, it indicates increase in strength of GDL solution there was a decrease in total score of LFP. It was found that higher level of $\mathrm{CMC}$ in milk $\left(\mathrm{B}^{2}\right)$ had significant $(\mathrm{P}<0.01)$ positive effect on total score, while higher level of strength of GDL solution $\left(\mathrm{C}^{2}\right)$ had significant $(\mathrm{P}<0.05)$ negative effect on total score at quadratic level. The interaction of level of CMC and strength of GDL solution $(\mathrm{BC})$ had significant $(\mathrm{P}<0.01)$ positive effect on total score of LFP (Fig. 1(d)).

Similar observation reported by Murtaza et al. (2017) who reported that with increases level of guar gum the overall acceptability score increased in low fat Cheddar cheese prepared from buffalo milk $(2.0 \%$ fat $)$. Thus the results are in agreement with those reported in literature. However, the results obtained in this study are in contrast to those reported by Ghosh et al. (2019). They reported that the total score of low-fat paneer prepared from $0.5 \%$ fat cow milk increased when milk coagulation temperature increase from 50 to $60^{\circ} \mathrm{C}$ and then decreased when coagulation temperature increase from 65 to $80^{\circ} \mathrm{C}$. Whereas, in our study, it was found that the highest total score was obtained when the coagulation temperature was $80^{\circ} \mathrm{C}$. The difference observed could be due to the differences in type and level of ingredients used and type of milk used. The flavour score of LFP was reduced while body and texture score as well as colour and appearance score was increased, resulting in rise in total score.

Effect of coagulation temperature, level of $\mathrm{CMC}$ and strength of GDL solution on textural properties and FDM of low-fat paneer
Textural properties selected as responses for LFP were Chewiness, Cohesiveness and Hardness and from composition FDM was selected. The values of these responses along with their factors as per run order are given in Table $1 . \mathrm{R}^{2}$ for hardness, chewiness, cohesiveness and FDM were $0.9253,0.8880,0.8446$ and 0.8619 respectively (Table 2 ).

\section{Hardness}

The values of hardness of LFP shown in Table 1 ranged from 13.68 to $28.23 \mathrm{~N}$. The values presented in Table 2 revealed with increase in coagulation temperature of milk (A) and strength of GDL solution $(C)$ there was a significant $(\mathrm{P}<0.01)$ increase in hardness of LFP. However, level of CMC showed significant $(\mathrm{P}<0.01)$ negative effect on hardness of LFP at linear level. The interaction of coagulation temperature of milk and strength of GDL solution (AC) had significant $(\mathrm{P}<0.01)$ positive effect on hardness of LFP (Fig. 2(a)). Increasing coagulation temperature and strength of GDL solution resulted in reduction in moisture content which led to increased hardness while increasing the level of CMC increased water-binding and thus moisture content of final product resulting in reduced hardness. Hardness of lowfat fibre supplemented paneer prepared from toned milk (3.0\% fat $/ 8.5 \% \mathrm{SNF})$ increased significantly $(\mathrm{P}<0.05)$ with increase in amount of citric acid solution and coagulation temperature (Singh et al. 2015) Murtaza et al. (2017) reported that increase in concentration of guar gum and xanthan gum (independently) from 0.15 to $0.45 \%$ there was a decrease in hardness $1399.54 \mathrm{~g}$ to $1321.78 \mathrm{~g}$ and $1440.23 \mathrm{~g}$ to $1389.00 \mathrm{~g}$ respectively of low-fat Cheddar cheese $(2.0 \%$ fat milk). 


\section{Chewiness}

The values of chewiness (Nmm) of LFP shown in Table 1 ranged from 39.37 to $85.21 \mathrm{Nmm}$. The observations from Table 2 suggested coagulation temperature and strength of GDL solution had positive correlation with chewiness of LFP. However, level of CMC had negative correlation with chewiness of LFP. Coagulation temperature of milk and strength of GDL solution $(A C)$ had significant $(\mathrm{P}<0.05)$ positive interaction effect on chewiness (Fig. 2(b)). Increasing coagulation temperature and strength of GDL resulted in reduced moisture and thus increased total solids as well as protein content while increasing the level of $\mathrm{CMC}$ resulted in higher moisture and lower total solids and protein in final product. Chewiness has direct relationship with protein content (Mistry, 2001). Similar results observed by Singh et al. (2015) who reported that coagulation temperature $(\mathrm{P}<0.05)$ and amount of citric acid solution $(\mathrm{P}<0.01)$ had significant positive effect on chewiness at linear level of low-fat fibre supplemented paneer made from 3.0\% fat and 8.5\% SNF. Similarly Murtaza et al. (2017) also reported that with increase in level of hydrocolloids xanthan gum and guar gum (independently) from 0.15 to $0.45 \%$ showed decrease in chewiness of low fat Cheddar cheese prepared from buffalo milk from ( $2.0 \%$ fat).

\section{Cohesiveness}

The values of cohesiveness of LFP shown in Table 1 ranged from 0.46216 to 0.52023 . The values from Table 2 suggested with increase in level of CMC there was a significant $(\mathrm{P}<0.01)$ decrease in cohesiveness of LFP. The interaction effect of level of CMC and strength of GDL solution $(\mathrm{BC})$ had significant $(\mathrm{P}<0.01)$ positive effect on cohesiveness of LFP (Fig. 2(c)). Reduction in cohesiveness with higher level of CMC could be ascribed to higher moisture content associated with higher CMC. Similarly to our results, Singh et al. (2015) also reported that the interaction of coagulation temperature and amount of citric acid solution had non-significant effect on cohesiveness of low-fat fibre supplemented paneer ( $3.0 \%$ fat milk). Similar results also observed by Murtaza et al. (2017) also reported that with increase in level of hydrocolloids viz. xanthan gum and guar gum (independently) from 0.15 to $0.45 \%$ resulted into decrease in the cohesiveness of low fat Cheddar cheese ( $2.0 \%$ fat milk) from 0.866 to 0.824 and 0.876 to 0.812 , respectively.

\section{Fat on Dry Matter (FDM)}

The values of FDM shown in Table 1 ranged from 17.00 to $22.15 \%$. The observations from Table 2 suggested with increase in level of CMC there was significant $(\mathrm{P}<0.05)$ increase in FDM of LFP. The interaction of coagulation temperature of milk and level of $\mathrm{CMC}(\mathrm{AB})$ showed significant $(\mathrm{P}<0.01)$ negative effect on FDM of LFP. Increasing the level of hydrocolloids such as CMC helps in retention of fat (Salari et al. 2017). Similar results observed by Murtaza et al. (2017) who reported that with increase in level of hydrocolloids (xanthan gum and guar gum independently) there was an increase in FDM content of low-fat Cheddar cheese prepared from buffalo milk (2.0\% fat).

\section{Optimization of low -fat paneer (LFP)}

Optimization of process for the development of LFP was carried out with the objective of determining the best possible combination(s) of different levels of factors viz. coagulation temperature, level of CMC and strength of GDL solution that would lead to the most acceptable product in terms of sensory characteristics.

The goals for all sensory responses were set to be maximized. The predicted formulation for optimized LFP from RSM analysis consisted of $79.67^{\circ} \mathrm{C}\left(\sim 80^{\circ} \mathrm{C}\right)$ coagulation temperature, $600 \mathrm{mg}$ CMC per kg milk (w/w of milk) and $2.0 \%$ GDL solution. The predicted sensory scores, textural properties and FDM of LFP are depicted in Table 3. The final product was manufactured employing the suggested formulation and the actual results obtained were compared with these predicted values of the criteria/responses selected for process optimization. The calculated $t$-values of for all the parameters are reported in Table 3 . The calculated t-values being less than the table values, it is inferred that there was non-significant $(\mathrm{P}<0.05)$ difference between the predicted and actual values of responses.

LFP prepared using the optimized solution was manufactured using $80^{\circ} \mathrm{C}$ coagulation temperature, @ $600 \mathrm{mg} / \mathrm{kg}$ milk CMC (w/ w of milk) and $2.0 \%$ GDL solution. The compositional, physicochemical, sensory characteristics and textural properties of the low-fat paneer (LFP) was compared with a paneer (CP) made by using citric acid ( $1 \%$ solution $\mathrm{w} / \mathrm{v})$ as a coagulant. The average values of the chemical composition of the developed reducedfat paneer i.e. LFP and CP are showed in Table 4. Moisture content of LFP is significantly $(\mathrm{P}<0.05)$ higher than that of $\mathrm{CP}$ due to addition of hydrocolloid such as $\mathrm{CMC}$ which translated into significantly $(\mathrm{P}<0.05)$ lower fat, protein and carbohydrate content as well as higher yield. Flavour score of LFP is significantly $(\mathrm{P}<0.05)$ lower due to flat flavor owing to higher moisture while colour and appearance score is significantly $(\mathrm{P}<0.05)$ higher due to more whiteness in LFP but total score of LFP remained significantly $(\mathrm{P}<0.05)$ lower. Hardness of LFP is significantly $(\mathrm{P}<0.05)$ lower while cohesiveness is significantly $(\mathrm{P}<0.05)$ higher due to higher moisture content. Yellamanda et al. (2006) reported acidity values of low-fat paneer prepared form milk containing $2.0 \%$ fat and $9.0 \%$ MSNF to be $0.42-0.43 \%$. According to FSSR (2011) standards for low fat paneer, a product can be qualified as low fat if it meets the following requirements: Moisture (max. $\% \mathrm{~m} / \mathrm{m}) 70 \%$ and milk fat $(\% \mathrm{~m} / \mathrm{m}$ on dry basis): $20 \%$ maximum. Based on the results obtained in this study, LFP can be classified as "Low-Fat Paneer" under the FSSR (2011) regulations, since it met the requirements with respect to moisture and fat content. 


\section{Conclusion}

Based on the results obtained in this study it can be concluded that the optimum parameters for manufacture of low-fat paneer using GDL as coagulant are: using a coagulation temperature of $80^{\circ} \mathrm{C}$, addition of $600 \mathrm{mg} / \mathrm{kg} \mathrm{CMC} \mathrm{(w/w)} \mathrm{of} \mathrm{milk} \mathrm{and} \mathrm{using} \mathrm{GDL} \mathrm{in}$ the form a $2.0 \%$ solution. The quantity of GDL required to coagulate one $\mathrm{kg}$ milk was 3.8 to $4.0 \mathrm{~g}$. The yield of paneer obtained was $13.4 \mathrm{~kg} / 100 \mathrm{~kg}$ milk. The product had $27 \%$ higher protein as compared to regular paneer. The fat content in the developed product was about 4 times lower than that of regular paneer. The developed product has a good potential of being marketed as a healthy alternative to paneer.

\section{References}

Aneja, RP, Mathur, BN, Chandan, RC, Banerjee, AK (2002) Heat-acid coagulated products. In: Gupta PR (ed) Technology of Indian Milk Products, Dairy India Yearbook, New Delhi, pp 133-142

Fetahagić S, Maćej OD, Denin-Đurđević JD, Jovanović ST (2002) The influence of GDL concentration on milk $\mathrm{pH}$ change during acid coagulation. J Agric Sci 47:75-85

FSSAI (2015) Manual of Methods for Analysis of Foods - Milk and Milk Products, Government of India, New Delhi, pp 54, 56, 135, 139, 143,145

FSSR (2011) Food Safety and Standards (Food Products Standards and Food Additives) Regulations, Ministry of family and health affair, Government of India, New Delhi, India

Ghosh D, Debnath A, Chetri A (2019) Effect of processing parameters on quality attributes of cow skim milk Paneer. Pharm Innovation J 8:429-431
Guo S, Ono T (2005) The role of composition and content of protein particles in soymilk on tofu curding by glucono- $\delta$-lactone or calcium sulfate. J Food Sci 70:258-262

IS: 15346 (2003) Method for Sensory Evaluation of Paneer/Chhana. Bureau of Indian Standards, Manak Bhavan, New Delhi

Lucey J, Kelly J (1994) Cheese yield. Int J Dairy Technol 47:1-14

Madadlou A, Khosrowshahi A, Mosavi ME (2005) Rheology, micro-structure and functionality of low-fat Iranian White cheese made with different concentration of rennet. J Dairy Sci 88:3052-3062

Mistry VU (2001) Low fat cheese technology. Int Dairy J 11:413-422

Murtaza MS, Sameen A, Huma N, Hussain F (2017) Influence of hydrocolloid gums on textural, functional and sensory properties of low fat Cheddar Cheese from buffalo milk. Pak J Zool 49:27-34.

Salari S, Zanganeh M, Fadavi A, Ahmadi Z (2017) Effect of xanthan gum and carboxymethyl cellulose on chemical and sensory properties of cream cheese. Int J Adv Manuf Technol 8: 2-6

Sandrou DK, Arvanitoyannis IS (2003) Low-fat/calorie foods: current state and perspectives. Crit Rev Food Sci Nutr 40:427-447

Shin W, Kim W, Kim Y (2014) Physicochemical and sensory characteristics of a low-fat tofu produced using supercritical $\mathrm{co}_{2}$ extracted soy flour. Food Sci Biotechnol 23:43-48

Singh G, Kumar A, Kumbhar BK, Dar BN (2015) Optimization of processing parameters and ingredients for development of low-fat fibre-supplemented paneer. J Food Sci Technol 52:709-719

Tufeanu R, Tiţa O (2016) Possibilities to develop low-fat products: a review. Acta Univ. Cibiniensis, Ser. E: Food Technol 20:3-19

Yellamanda S, Reddy K, Devi LN (2006) A Study on pickling of low fat paneer. Indian J Dairy Sci 59:125-127 